\title{
Comparing generations of migrants' transnational behaviour: the role of the transnational convoy and integration
}

\author{
Jolien Klok ${ }^{1 *}$ (D) Theo van Tilburg ${ }^{2}$, Tineke Fokkema ${ }^{1,3}$ and Bianca Suanet ${ }^{2}$
}

\footnotetext{
* Correspondence: j.klok@essb.eur.nl 1 Department of Erasmus School of Social and Behavioural Sciences, Erasmus University Rotterdam, Burgemeester Oudlaan 50, 3062, PA Rotterdam, The Netherlands Full list of author information is available at the end of the article
}

\begin{abstract}
This paper compares generations (G1, G1.5, G2, G3) of male Turkish migrants to Europe in their transnational behaviours: contact frequency, visits, remittances, property ownership and voting. We aim to explain differences by generational differences in transnational convoy size and integration into residence countries. Data from 798 members of migrant families were obtained from 2000 Families. Generations differ in visiting, remitting, property ownership and voting, but not in contact frequency. Using regression analysis, the transnational convoy cannot explain transnational behaviours. Structural and socio-cultural integration impact various transnational behaviours within generations. Generally, waning of transnational ties across generations cannot be attributed to differences in transnational ties or integration. We add to knowledge on generational differences in transnational behaviour until the third generation and on determinants of transnational behaviour, but conclude that the field of transnational studies is in need of further refinement of operationalization and theory to understand generational differences in transnational behaviour.

Keywords: Transnational behaviour, Generational comparison, Turkish migrants, Transnational convoy, Integration
\end{abstract}

\section{Introduction}

Transnational studies provide knowledge of how migrants' lives are simultaneously embedded in residence and origin countries (Glick Schiller et al. 1992). To understand social change in societies that are impacted by migration, it is important to grasp how transnational connections change with generations (Ryder 1965). Acknowledging this, scholars have studied second-generation transnational involvements (Wessendorf 2013), and concluded that the frequency and intensity of their transnational activities diverge from those of their parents (Levitt and Glick Schiller 2004). However, exactly how different generations of migrants compare to the first generation in their transnational behaviours is still poorly investigated (Safi 2017). In this paper, we first aim to provide a detailed image of how migrant generations, until the third generation, differ in transnational behaviours. We distinguish consecutive generations of male 'migrants'

(c) The Author(s). 2020 Open Access This article is licensed under a Creative Commons Attribution 4.0 International License, which permits use, sharing, adaptation, distribution and reproduction in any medium or format, as long as you give appropriate credit to the original author(s) and the source, provide a link to the Creative Commons licence, and indicate if changes were made. The images or other third party material in this article are included in the article's Creative Commons licence, unless indicated otherwise in a credit line to the material. If material is not included in the article's Creative Commons licence and your intended use is not permitted by statutory regulation or exceeds the permitted use, you will need to obtain permission directly from the copyright holder. To view a copy of this licence, visit http://creativecommons.org/licenses/by/4.0/. 
from Turkey to Europe and examine five behaviours: contact frequency, visits, remittances, property ownership and voting. Our second aim is explaining the differences in transnational behaviour by generational differences in three domains of social involvement, i.e., transnational ties and structural and socio-cultural integration into the residence country. Transnational ties are gauged by a 'transnational convoy': having close ties in the origin country. Structural integration involves a person's position in various domains of stratification. Socio-cultural integration refers to behavioural and affective conformity to the residence society.

The scarce literature considering generations when studying transnational behaviour often employed generational status as an indicator for social processes. For instance, Schans (2009) interpreted generational status as differences in transnational family ties, Tamaki (2011) as variations in exposure to the residence country, and Waldinger (2008) as disparities in social and affective attachments. Consequently, what 'generation' means for transnational behaviour has not been studied extensively. In this paper, we intend to open the black box called 'generation' in transnational behaviour. We do so using a unique large-scale dataset on multiple generations of Turkish migrants (Guveli et al. 2016).

\section{Differences in transnational behaviour across generations}

Transnational behaviours can be distinguished into various domains. Social transnational behaviour refers to the ways in which migrants and their offspring stay connected to origin country inhabitants, such as contact by information and communication technology (ICT) and visits (Mason 2004). Remittance sending is a form of economic transnational behaviour and often represents the key motivation to migrate (Carling 2008). Owning property in the origin country is also classified as economic transnational behaviour; it fosters symbolic and emotional ties to the origin country (Dalakoglou 2010). Voting in elections is the most notable of political transnational behaviour (Boccagni et al. 2016). It voices an interest in the country's destiny and opposition or support for the homeland political regime (Østergaard-Nielsen, E. 2001).

By now it is established that border-crossing activities are simply part of the migration process and that transnational behaviours for first generation migrants are ubiquitous (Schunck 2014; Vertovec 2009; Waldinger 2008). As children of immigrants are raised in households where transnational connections are the order of the day, they also employ transnational behaviours (Mason 2004; Fokkema et al. 2012; Mügge 2011). These are, however, in general less frequent and intense as those of their parents (Levitt 2009; Schunck 2014; Tamaki 2011; Trieu et al. 2016). About the transnational behaviours of grandchildren of migrants not much is known. Even more so, the descendants of migrants are often lumped together (Trieu et al. 2016; Leichtman 2005), even though the differences in their starting point in relation to the origin country is salient. Generation one-and-a-half (G1.5) was born in the origin country and migrated with parents before the age of thirteen (Rumbaut 2004). The second generation (G2), in contrast, was born in the migration country (King and Christou 2010) whereas the third generation (G3) was born in the residence country from parents who were also born there (Alba et al. 2002). This difference in genesis could perhaps make personal attachments to the origin country significantly different (Trieu et al. 2016). Based on previous 
comparisons of transnational behaviours between the first and the second generation (Safi 2017) we first hypothesise (Hypothesis 1): Transnational behaviour diminishes across generations.

In the following, we describe how generations differ in transnational convoy relationships and structural and socio-cultural integration (Hypotheses 2a, 3a and 4a) and how these factors impact transnational behaviour (Hypotheses $2 \mathrm{~b}, 3 \mathrm{~b}$ and $4 \mathrm{~b}$ ).

\section{Connecting to a transnational convoy}

Research suggests that generations differ in the importance of transnational relationships for transnational involvement (Safi 2017). Where first generation migrants' transnational behaviours would mainly be triggered by transnational relationships (Itzigsohn 2002), the second generation's would be more reliant on reception contexts (Espiritu 2003). No convincing support for this idea was found in comparative research (Safi 2017). Consequently, we do not differentiate in explanations for different generation's transnational behaviour. Instead, a more general rationale is employed for all generations.

In a personal network social support is given and received to enhance wellbeing and sustain relationships. The well-known convoy model of social relations (Kahn and Antonucci 1980) was proposed as the structure in which these support exchanges take place. The convoy model is depicted as a set of three concentric circles. Each of these circles represents a different degree of closeness to the focal person, with the first circle conveying people from the social network to whom one is closest, and the third circle with members to whom one is least close. The convoy surrounds a person going through life and is subject to situational changes. Colleagues, for instance, are often only temporarily involved, hence they are situated in the third circle. Other connections in the convoy, like close family members in the first circle, take a sustained form throughout life. International migration implies a major disjuncture of a person's social life. Migrants leave social convoys in departure countries and face the challenge of forming new convoys in residence countries. It is likely that some members of the social convoy in the origin country, especially close ties, remain involved in migrants' lives. This is not only true for first-generation migrants. Scholars observed that children of migrants are socialised into their parents' social networks and lifestyles, spanning countries of residence and origin (Levitt 2009). We consider close ties in the origin country that remain involved in migrants' - and their children's - lives the transnational convoy. We explicitly choose to use this term from work on the life course and gerontology because we aim to demarcate a specific portion of the more broadly used 'social network'. We argue that especially close ties are likely to accompany a person throughout large parts of life - if not forever - and are therefore important relationships to maintain, for each generation. We reason that different generations have different transnational convoy sizes.

G1 migrated in adulthood and spent formative and young adulthood years in the origin country. This enabled the development of substantive social networks there, including many close ties. G1.5 dwelled some - although maybe short - times in a country their parents grew up in and leave it in a different social context than those preceding them. Their transnational convoy is presumably smaller, containing fewer close ties in comparison to G1. G2 was raised in their ancestors' residence country and entered 
social networks in Europe. They never resided in parental origin countries and are likely to possess even fewer close-knit ties there than G1.5 or G1 (Fokkema et al. 2013). G3 can hardly be called 'migrant'. G3's social connectedness with the origin country is first and foremost a spinoff from their parents' and grandparents' transnational networks (Levitt and Jaworsky 2007), leaving them with an even smaller transnational convoy than their predecessors. Hypothesis 2a reads: Earlier generations have greater transnational convoys than later generations.

In the process of maintaining transnational convoys, migrants and their descendants employ transnational behaviours, as discussed above. Greater transnational convoys require greater investment and thus more transnational behaviour to uphold relationships. Closing the path between generations, transnational convoys and transnational behaviour, Hypothesis $2 \mathrm{~b}$ is: The greater the transnational convoy, the more transnational behaviour.

\section{Integration}

A second explanation for generational variety in transnational behaviour calls upon integration into the residence country (Safi 2017). We distinguish structural and sociocultural integration. Structural integration pertains to levels of education and labour market positions (Snel et al. 2006). Socio-cultural integration encompasses less tangible features, such as language competence (Ersanilli and Koopmans 2010), feelings of belonging (Erdal and Oeppen 2013), and informal contact with the majority population (Dagevos 2001).

Although not always clearly linearly shaped and notwithstanding discriminatory practices impeding structural integration, research confirms that later generations 'do better' in terms of educational and labour market accomplishments than earlier generations (Algan et al. 2009; Crul and Vermeulen 2003). Accordingly, Hypothesis 3a reads: Later generations are more structurally integrated into the residence society than earlier generations.

Research suggests that socioeconomic resources are required to behave transnationally (Carling and Hoelscher 2013; Tamaki 2011). For instance, migrants (and their descendants) need money and familiarity with institutional and legal procedures to visit the origin country, remit, vote or own property there. We introduce Hypothesis 3b: The more structural integration into the residence society, the more transnational behaviour.

We expect (Hypothesis 4a) later generations are more socio-culturally integrated into the residence society, as they lived there longer than earlier generations (Rumbaut 2004). Indeed, duration of residence is sometimes used as indicator of socio-cultural integration (Waldinger 2008).

Theorising how socio-cultural integration relates to transnational behaviour is a more complicated venture. We depart from the idea that socio-cultural engagements are finite; migrants and their descendants invest in the country to which they feel greater belonging and attachment. Consequently, simultaneous participation in the other country becomes limited (Levitt 2003). Supportive findings show that a longer length of residence and citizenship in the residence country decreases the frequency of contact with origin country-based relatives (Schans 2009). Even so, citizenship would reduce voting in home elections, remitting, and visiting (Waldinger 2008). This indicates a 
straightforward relationship between socio-cultural integration and transnational behaviour: more of one is associated with less of the other. In our view, this relationship is more ambiguous. We suggest that little socio-cultural integration into the residence society may be compensated for in two ways. First, by employing transnational behaviour. Social and cultural embedding is then sought in the origin country (Glick Schiller et al. 1992). A second strategy is to pursue these in the migrant community and seek comfort from people from the origin country in the residence country (Ehrkamp 2005). Integration into one of these social avenues is not static. Migrants and their descendants are likely to combine different socio-cultural strategies at specific times (Levitt and Glick Schiller 2004). However, one of those presented above could become dominant at certain times. Because our aim is to understand generational differences in transnational behaviour and not socio-cultural integration in varying forms, Hypothesis $4 \mathrm{~b}$ states: The more socio-cultural integration into the residence society, the less transnational behaviour.

Pertaining to Hypotheses $3 \mathrm{~b}$ and $4 \mathrm{~b}$, expecting that integration is related to transnational behaviours: both integration and transnational behaviours are broad, multidimensional concepts in need of conceptual development and clarification (Boccagni 2012; Scholten 2011). We formulated the hypotheses in more overarching ways but do not disregard the possibility that (dimensions of) the mechanisms proposed influence the five transnational behaviours in differing ways and to various extents. In Fig. 1 a conceptual model of the hypotheses is presented.

\section{Methods}

\section{Sample}

Data come from 2000 Families: Migration histories of Turks in Europe (Guveli et al. 2016), and were collected from 2010 to 2012. It explores, among other topics, migration processes among Turkish migrant and non-migrant families and their members across four generations. Hundred units (rural villages or urban streets) were randomly sampled using population registers in five migrant sending regions in Turkey (Ganzeboom et al. 2015). After arriving at a unit, interviewers knocked on every door in rural areas and followed a skip-one-door rule in urban areas, turned left at the end of the street and right at the end of the next. Migrant families - non-migrant families are not used in the current study - were selected based on having a male ancestor who 1) may be dead or alive; 2) is or would have been between 65 and 90 years old; 3) grew up in the region; 4) moved to Europe between 1960 and 1974; and 5) stayed there. Ancestors and descendants were

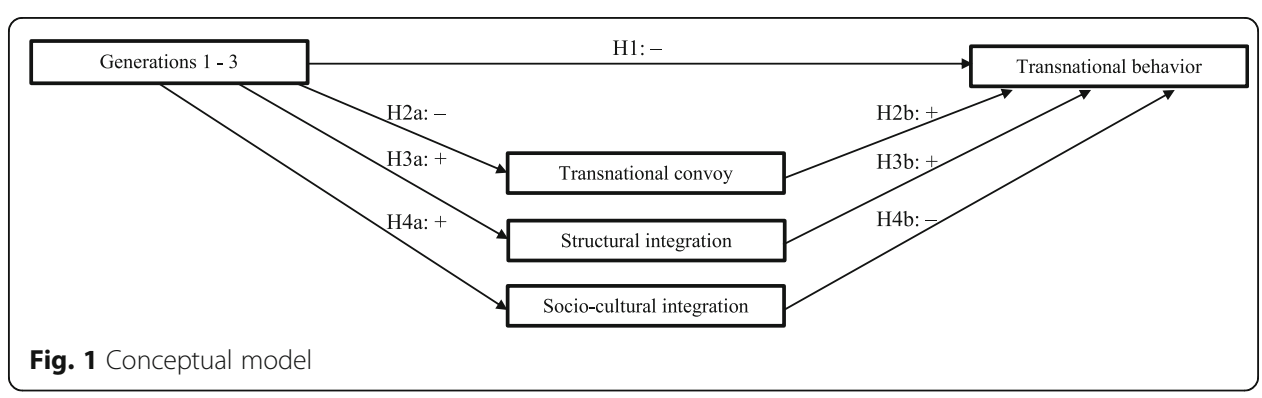


traced across Europe. To sample second and third generation members, first names were alphabetically ordered; the first and last were recruited.

We selected respondents who participated in personal interviews (predominantly by telephone) (Fig. 2). As the first wave of labour migrants from Turkey to Europe was almost exclusively male, the 2000 Families Survey sampled only men for the first generation. We consequently selected only men in the subsequent generations. We excluded respondents not living in Europe and those living in two countries (mostly Turkey in addition to a West-European country). The remaining sample contained people from G4, who were excluded.

Two variables offered information on current place of residence. The first ("In which country do you live?") was used to exclude everyone not living in Europe (upper part of Fig. 2). The second contained information on current place of residence and migration history (lower part of Fig. 2). Four subsamples were derived. G1 comprises firstgeneration migrants born in Turkey leaving for Europe after their eighteenth birthday, $N=250$. G1.5 is a subsample of the demographic second generation. G1.5 includes those who were born in Turkey and left the country for Europe before the age of thirteen, presumably along with their parents, and stayed there, $N=171$. G2 consists of those born in Europe, from Turkish migrants, who are still residing in Europe, $N=118$. G3 is composed of the demographic third generation and includes people who were born in Europe and stayed there, $N=259 . N=38$ persons of G3 are children from G1.5 and are, according to migration literature, second generation migrants. $N=4$ persons of G3 are children from our sample G2 and are thus 'genuine' third generation migrants; those born in the country of settlement, whose grandparent(s) were born abroad but whose parents were not (Alba et al. 2002). Of the other people in our G3 sample, we do not have information on whether their parents are G1.5 or G2. Table 1 displays how the (family study) data structure relates to our migration literature inspired sample

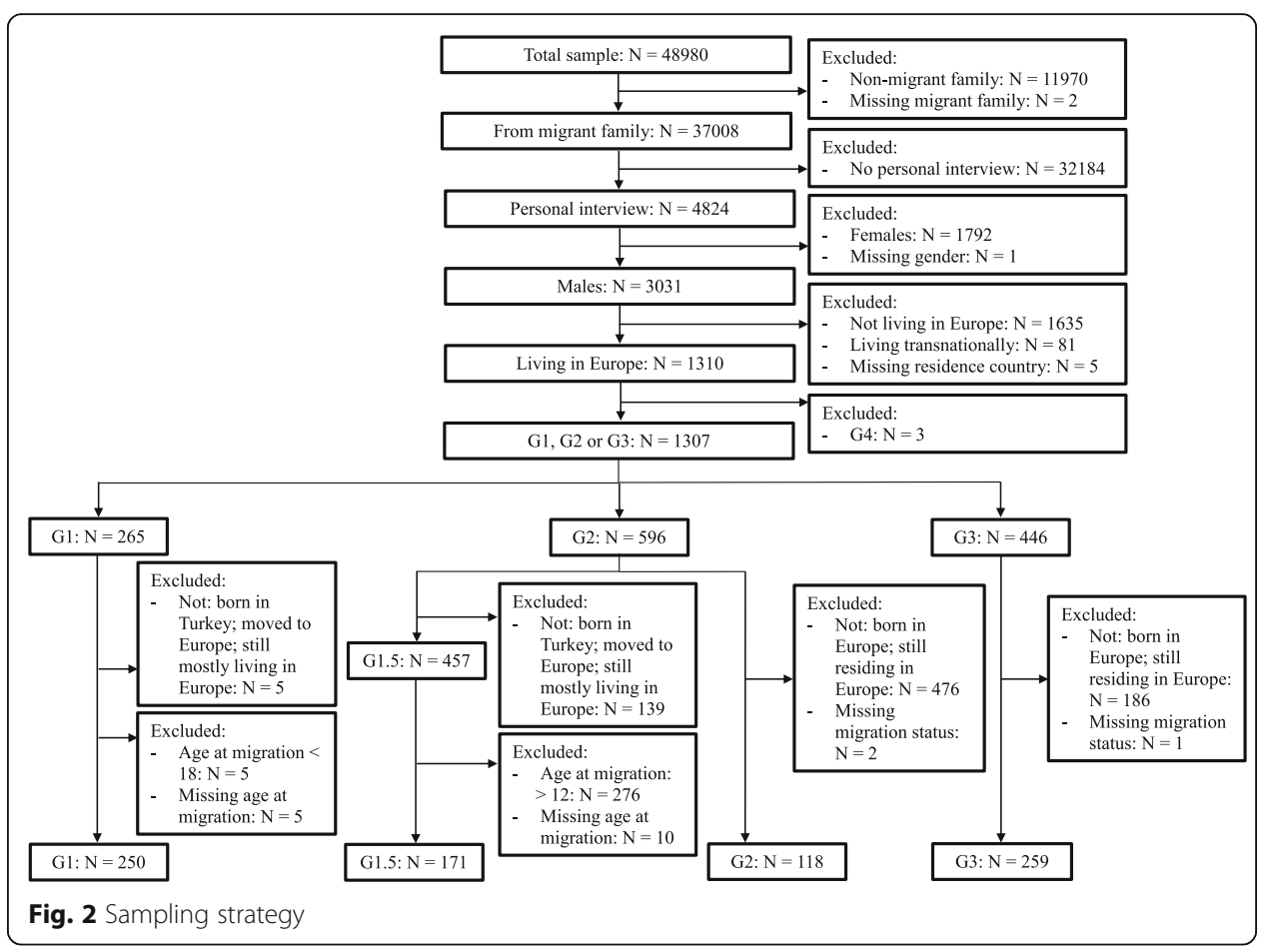


Table 1 Samples' relation to (data) family structure

\begin{tabular}{lllll}
\hline & $\begin{array}{l}\text { Migrant in } \\
\text { adulthood }\end{array}$ & $\begin{array}{l}\text { Migrant before } \\
\text { age thirteen }\end{array}$ & $\begin{array}{l}\text { Father is migrant; born } \\
\text { in Europe }\end{array}$ & $\begin{array}{l}\text { Grandfather is migrant; } \\
\text { born in Europe }\end{array}$ \\
\hline $\begin{array}{l}\text { Grandfather } \\
\text { G1 }\end{array}$ & G1.5 & G2 & \\
Father & & G3 & G3 \\
Grandson & & & G
\end{tabular}

composition. Although the data consist of families, our subsamples are not fully related: $61 \%$ of the respondents are the only ones from their family participating in our study; $39 \%$ have a participating relative. This means that (grand)children of first-generation return- or deceased migrants, who are in the data but not in our G1, can be a part of our G1.5, G2 or G3.

\section{Measurements}

\section{Transnational behaviour}

Contact indicated how often one is in contact (by phone, texting, email, internet, letter, or in person) with friends or relatives (excluding parents) living in Turkey. Answers varied between "less than a few times a year or never" (coded 1) and "most days" (5). Visits measured how many times Turkey was visited in the last 5 years. Remittances assessed whether respondents had sent money to Turkey to support family, friends or the local community in the last twelve months. Property evaluated whether one owned a house, business or land (shared or full ownership) in Turkey. Voting assessed whether one had voted in Turkey's national election of June 2011.

\section{Transnational convoy}

We assessed whether parents were alive and where they lived. When at least one parent lived in Turkey, we coded 1, otherwise 0. In G1.5 and G2, there were six and nine respondents, respectively, indicating that their parent(s) were living in Turkey and in another country. We coded them 1. Making use of several variables, close people counted the number of close people living in Turkey. One question was formulated: "Let us now talk a bit about the people who are important to you and who you feel close to". Parents, partners and children were supposed to be excluded; other relatives could be included. For the first three mentioned, residence country was asked. We coded three close members in Turkey as two because of a low frequency.

\section{Structural integration}

Level of education, i.e., from "primary drop out" (1) to "higher tertiary" (10), and having a paid job assessed migrants' structural position in society. Another variable indicated whether one owned property in the residence country (a house, business or land; shared or full ownership).

\section{Socio-cultural integration}

We used residence country language proficiency with response options varying from "not very well or not at all" (1) to "very well" (3). "How closely do you feel connected with [country] nationals?" with answers ranging from "not at all" (1) to 
"entirely connected" (5) was gauged in connectivity with residence country nationals. We captured religious attendance to account for integration into the migrant community in the residence country (Ehrkamp 2005). Answers varied between "never" (1) and "every day" (6). We further considered having a Turkish partner (Fokkema and De Haas 2015).

\section{Control variables}

Poor health limits the ability to behave transnationally (Bolzman 2013). Self-rated health varied between "poor" (1) and "excellent" (5). We also controlled for age. Residence country shows where respondents live in Europe. Residence countries that were home to less than $10 \%$ of the total sample were grouped into 'other countries' consisting of Austria, Denmark, Italy, Sweden and Switzerland.

\section{Procedure}

Depending on measurement levels, we used ANOVA, Kruskal Wallis and $\mathrm{Chi}^{2}$ tests to evaluate generational differences in transnational behaviour, transnational convoy and integration. We thereby tested Hypotheses 1, 2a, 3a and 4a. When the overall test showed significant results, we analysed which generations differed from each other using Bonferroni, Mann-Whitney $\mathrm{U}$ and $\mathrm{Chi}^{2}$ tests. We do not control for socio-demographic factors (such as age and socio-economic status) here. Lifecourse effects in a generational comparison such as employed here cannot be controlled for, as socio-demographic factors are at the heart of what constitutes the different generations. The five dependent variables (contact frequency, visiting, remitting, property ownership and voting) revealed low correlations (Pearson or Spearman $r$.25). Consequently, we analysed them separately. We used multiple imputations to handle the missing data (Table 2), for which we included the dependent variables used in the regression analyses (Von Hippel 2007), with twenty iterations. Descriptive statistics and differences between generations did not differ much before and after imputation (results not shown).

To test Hypotheses 2b, 3b and 4b we employed linear, and binomial and ordinal logistic regression analyses of four (non-imputed) indicators of transnational behaviour. In G2 and G3, very few people voted in Turkey's national election, causing insufficient variance for the statistical analyses to produce any meaningful estimates. Hence, we left out regression analysis for voting. We used imputed independent variables. Model 1 shows how subsequent generations differ from G1, controlled for self-rated health, age and country of residence. Model 2 tests whether indicators of the transnational convoy, structural and socio-cultural integration can be held accountable for the generational differences in transnational behaviour. (In the supplementary material we additionally present the findings of bivariate regressions with only one explanatory concept). Dummy variables were used for generations. Age was centred per generation to prevent collinearity with the generation variables. Model fitting indices were generated for each of the twenty imputed datasets. Models were compared by the $F$-change statistic or by testing whether deviance in the -2 log likelihood was significantly reduced. Multicollinearity testing did not reveal problems. 


\section{Results}

Table 2 presents descriptive statistics of all (non-imputed) variables used in the analyses. Table 3 shows whether generations' average scores on these variables differ significantly. Frequency of transnational contact averages between 3.4 and 3.6 across the generations, i.e., between 'once a month' and 'once a week'; the differences are non-significant. G1, on average, visits Turkey about once a year. The average number of visits (displayed per 5 years) decreases across generations. Regarding remittances, only G3 substantially deviates; where on average, approximately half of all respondents among earlier generations remit, for G3 this is only a third. Owning property in Turkey shows a downward pattern across generations, from $90 \%$ of G1 to a third of G3 respondents. In voting, only G1 is markedly represented: $43 \%$ voted. We find partial support for Hypothesis 1: Transnational behaviour is diminishing from first to third generation for four transnational behaviours, though not always in a linearly decreasing form.

Table 2 Descriptive statistics before imputation

\begin{tabular}{|c|c|c|c|c|c|c|c|c|c|c|c|c|}
\hline & \multicolumn{3}{|c|}{$\mathrm{G} 1 \mathrm{~N}=\mathbf{2 5 0}$} & \multicolumn{3}{|c|}{$\mathrm{G} 1.5 \mathrm{~N}=171$} & \multicolumn{3}{|c|}{$G 2 N=118$} & \multicolumn{3}{|c|}{ G3 $N=259$} \\
\hline & $M / \%$ & SD & $\mathrm{N}$ & $\mathrm{M} / \%$ & SD & $\mathrm{N}$ & $\mathrm{M} / \%$ & SD & $\mathrm{N}$ & $\mathrm{M} / \%$ & SD & $\mathbf{N}$ \\
\hline \multicolumn{13}{|l|}{ Transnational behaviour } \\
\hline Contact (1-5) & 3.61 & 1.16 & 236 & 3.49 & 1.26 & 170 & 3.39 & 1.33 & 116 & 3.41 & 1.26 & 256 \\
\hline Visits (per five years) (0-30) & 5.53 & 2.43 & 243 & 4.66 & 3.06 & 170 & 4.30 & 2.84 & 114 & 3.85 & 2.54 & 253 \\
\hline Remittances (0-1) & 0.53 & 0.50 & 236 & 0.55 & 0.50 & 167 & 0.51 & 0.50 & 118 & 0.28 & 0.45 & 253 \\
\hline Property (0-1) & 0.91 & 0.28 & 234 & 0.63 & 0.49 & 161 & 0.41 & 0.50 & 109 & 0.33 & 0.47 & 248 \\
\hline Voting (0-1) & 0.43 & 0.50 & 221 & 0.08 & 0.27 & 161 & 0.03 & 0.16 & 114 & 0.02 & 0.16 & 241 \\
\hline \multicolumn{13}{|l|}{ Transnational convoy } \\
\hline Parents in Turkey (0-1) & 0.06 & 0.24 & 248 & 0.35 & 0.48 & 167 & 0.26 & 0.44 & 114 & 0.04 & 0.19 & 256 \\
\hline Close people in Turkey (0-2) & 0.63 & 0.71 & 175 & 0.37 & 0.63 & 138 & 0.23 & 0.51 & 97 & 0.20 & 0.49 & 215 \\
\hline \multicolumn{13}{|l|}{ Structural integration } \\
\hline Level of education (1-10) & 2.17 & 1.21 & 220 & 5.45 & 2.15 & 163 & 6.44 & 1.78 & 115 & 6.83 & 1.47 & 241 \\
\hline Having a paid job (0-1) & 0.06 & 0.25 & 247 & 0.86 & 0.35 & 168 & 0.85 & 0.36 & 117 & 0.57 & 0.50 & 253 \\
\hline Property in residence country $(0-1)$ & 0.47 & 0.50 & 216 & 0.69 & 0.47 & 154 & 0.50 & 0.50 & 107 & 0.36 & 0.48 & 236 \\
\hline \multicolumn{13}{|l|}{ Socio-cultural integration } \\
\hline $\begin{array}{l}\text { Residence country language } \\
\text { proficiency (1-3) }\end{array}$ & 1.56 & 0.61 & 220 & 2.32 & 0.55 & 155 & 2.41 & 0.60 & 111 & 2.45 & 0.53 & 233 \\
\hline $\begin{array}{l}\text { Connectivity with residence country } \\
\text { nationals }(1-5)\end{array}$ & 2.68 & 1.16 & 239 & 2.86 & 1.00 & 170 & 3.07 & 1.06 & 117 & 3.23 & 0.96 & 254 \\
\hline Religious attendance (1-6) & 5.09 & 1.35 & 248 & 4.05 & 1.34 & 167 & 3.97 & 1.36 & 117 & 4.04 & 1.32 & 254 \\
\hline Turkish partner (0-1) & 0.92 & 0.28 & 241 & 0.88 & 0.32 & 165 & 0.70 & 0.46 & 115 & 0.27 & 0.45 & 242 \\
\hline \multicolumn{13}{|l|}{ Control variables } \\
\hline Self-rated health (1-5) & 2.74 & 0.98 & 248 & 3.29 & 0.94 & 171 & 3.47 & 0.94 & 118 & 3.66 & 0.77 & 257 \\
\hline Age (18-90) & 70.73 & 5.48 & 250 & 42.12 & 5.80 & 171 & 32.61 & 4.78 & 118 & 23.24 & 4.23 & 259 \\
\hline Residence countries & & & 250 & & & 171 & & & 118 & & & 259 \\
\hline Germany & 0.32 & & & 0.35 & & & 0.31 & & & 0.38 & & \\
\hline Belgium & 0.25 & & & 0.28 & & & 0.33 & & & 0.23 & & \\
\hline France & 0.16 & & & 0.12 & & & 0.15 & & & 0.09 & & \\
\hline Netherlands & 0.13 & & & 0.08 & & & 0.12 & & & 0.13 & & \\
\hline Other countries & 0.13 & & & 0.18 & & & 0.09 & & & 0.18 & & \\
\hline
\end{tabular}


Table 3 Differences between generations before imputation

\begin{tabular}{|c|c|c|c|c|c|c|}
\hline & $\begin{array}{l}\text { G1 vs. } \\
\text { G1.5 }\end{array}$ & $\begin{array}{l}\text { G1 vs. } \\
\text { G2 }\end{array}$ & $\begin{array}{l}\text { G1 vs. } \\
\text { G3 }\end{array}$ & $\begin{array}{l}\text { G1.5 vs. } \\
\text { G2 }\end{array}$ & $\begin{array}{l}\text { G1.5 vs. } \\
\text { G3 }\end{array}$ & $\begin{array}{l}\text { G2 vs. } \\
\text { G3 }\end{array}$ \\
\hline \multicolumn{7}{|l|}{ Transnational behaviour } \\
\hline \multicolumn{7}{|l|}{ Contact (1-5) } \\
\hline Visits (per 5 years) $(0-30)$ & $* *$ & $* * *$ & $* * *$ & & * & \\
\hline Remittances (0-1) & & & $* * *$ & & $* * *$ & $* * *$ \\
\hline Property (0-1) & $* * *$ & $* * *$ & $* * *$ & $* *$ & $* * *$ & \\
\hline Voting (0-1) & $* * *$ & $* * *$ & $* * *$ & & $*$ & \\
\hline \multicolumn{7}{|l|}{ Transnational convoy } \\
\hline Parents in Turkey (0-1) & $* * *$ & $* * *$ & & & $* * *$ & $* * *$ \\
\hline Close people in Turkey (0-2) & $* * *$ & $* * *$ & $* * *$ & & $* *$ & \\
\hline \multicolumn{7}{|l|}{ Structural integration } \\
\hline Level of education (1-10) & $* * *$ & $* * *$ & $* * *$ & $* * *$ & $* * *$ & \\
\hline Having a paid job (0-1) & $* * *$ & $* * *$ & $* * *$ & & $* * *$ & $* * *$ \\
\hline Property in residence country $(0-1)$ & $* * *$ & & * & $* *$ & $* * *$ & $*$ \\
\hline \multicolumn{7}{|l|}{ Socio-cultural integration } \\
\hline Residence country language proficiency (1-3) & $* * *$ & $* * *$ & $* * *$ & & * & \\
\hline Connectivity with residence country nationals $(1-5)$ & & $* *$ & $* * *$ & & $* * *$ & \\
\hline Religious attendance (1-6) & $* * *$ & $* * *$ & $* * *$ & & & \\
\hline Turkish partner (0-1) & & $* * *$ & $* * *$ & $* * *$ & $* * *$ & $* * *$ \\
\hline \multicolumn{7}{|l|}{ Control variables } \\
\hline Self-rated health (1-5) & $* * *$ & $* * *$ & $* * *$ & & $* * *$ & * \\
\hline Age (18-90) & $* * *$ & $* * *$ & $* * *$ & $* * *$ & $* * *$ & $* * *$ \\
\hline Residence countries & & & & & & * \\
\hline
\end{tabular}

As G1 has a mean age of almost 71, it is not surprising that only few people have a parent living in Turkey. Among G1.5 and G2, approximately one-third of the respondents have a parent in Turkey. In G3, hardly anyone reported having a parent in Turkey. There are few respondents having close people in Turkey. G1 has the most with a mean of .6 (scaling is 0-2) persons. For G1.5, this is .4, and for G2 and G3, this is .2. We find partial support for Hypothesis 2a: Earlier generations have greater transnational convoys than later generations.

For structural integration, we observe an ascending pattern for educational level across generations. Unsurprisingly, G1 is often not employed. G3's lack of employment is explained by many people who are still in education. In G1.5 and G2, approximately $85 \%$ have a paid job. We observe a descending configuration for property ownership in the residence country, with G1.5 most often owning property and G1 being similar to G2. Partial support is found for Hypothesis 3a: Later generations are more structurally integrated into the residence society than earlier generations.

Among socio-cultural indicators, residence country language proficiency improves along generations, with G1 averaging between "not very well or not at all" and "well" and G1.5 to G3 all averaging between "well" and "very well". The later the generation, the more connectivity with residence country nationals is experienced, although all generations cluster around "somewhat connected" (extremes being $\mathrm{M}=2.7$ for G1 and $\mathrm{M}=3.2$ for G3). Religious attendance decreases across generations, but again, G1 
significantly deviates (on average going weekly) from the other generations (on average going monthly), while the rest show no differences. Although the number of people who report having a partner whose origins lie in Turkey decreases across generations, the percentages of Turkish partnerships are consistently high across generations. With a mean age of 23 in G3, it is not surprising that their number of (Turkish) partners is substantially lower. Although not always showing an evenly descending pattern, we found support for Hypothesis 4a: Later generations are more socio-culturally integrated into the residence society than earlier generations.

Regarding control variables, obviously later (and younger) generations report being healthier than earlier generations. Age varies greatly: G1 is on average 71 years old and G3 23. Main residence country is Germany, followed by Belgium, France and the Netherlands. Only G2 and G3 differ in the composition of residence countries. This difference is mainly found in the extent to which they live in Belgium and in 'other countries': G3 more often lives in Sweden in comparison to G2, the difference being five percentage points.

Table 4 presents results from regression analyses of transnational behaviour. In Model 1, only generations and control variables are incorporated. Model 2 includes all variables. Generations did not differ in contact frequency with friends and family in Turkey, meaning that we cannot explain differences in transnational behaviour between them. We observe that transnational convoy, nor structural integration is related to transnational contact frequency. One indicator of socio-cultural integration is significant (Hypothesis $3 \mathrm{~b})$ : religious attendance $(\mathrm{B}=.15)$. Those attending every day are 17 percentage points more likely to have contact on most days, in comparison to those who never go. People who live in 'other' countries are less likely to have transnational contact in comparison to those living in Germany $(B=.41)$, though in practice the difference between them is less than one percentage point, for all categories of contact frequency. Testing with other reference countries produces similar associations (results not shown). (Table S1 in the Supplementary Material further reveals that when controlled for structural integration only (Model 3), differences between G2 and G3 on the one side and G1 on the other, are reinforced and become significant.) The -2 log likelihood of Model 1 is not reduced in Model 2. Variation in the transnational convoy and integration are consequently not enlarging our comprehension of contact frequency, even despite individual variables yielding significant effects.

Generations differ on all other transnational behaviours, and support was found for later generations having smaller transnational convoys (Hypothesis 2a, partially) and being more structurally (Hypothesis 3a, partially) and socio-culturally (Hypothesis 4a) integrated. We can thus test whether generational differences in transnational behaviour can be understood by means of our explanatory framework.

For visiting Turkey, contrary to Hypothesis 2b, the transnational convoy is not meaningful. Two indicators of structural and one of socio-cultural integration play a role in understanding visiting. Having a paid job $(\mathrm{B}=.53)$ and owning property in the residence country $(\mathrm{B}=.53)$ are associated with more visits (Hypothesis $3 \mathrm{~b}$ ). A stronger connection to residence country nationals relates to fewer visits to the origin country $(B=-.24)$ (Hypothesis $4 \mathrm{~b}$ ). Controlled for measures of integration (and transnational convoy), those living in France $(\mathrm{B}=.89)$ and in 'other' countries $(B=.61)$ visit more in comparison to those in Germany. Changing reference 


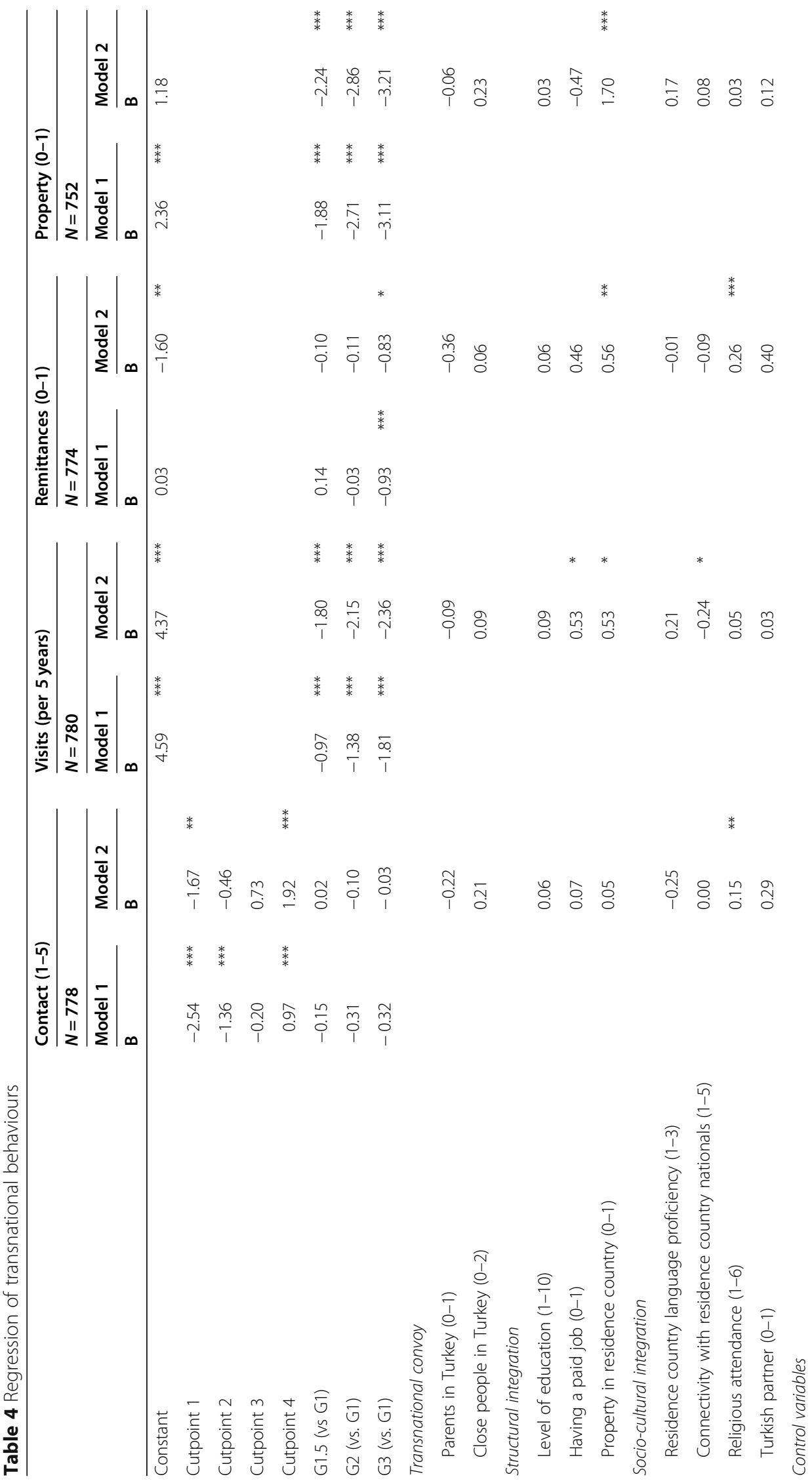




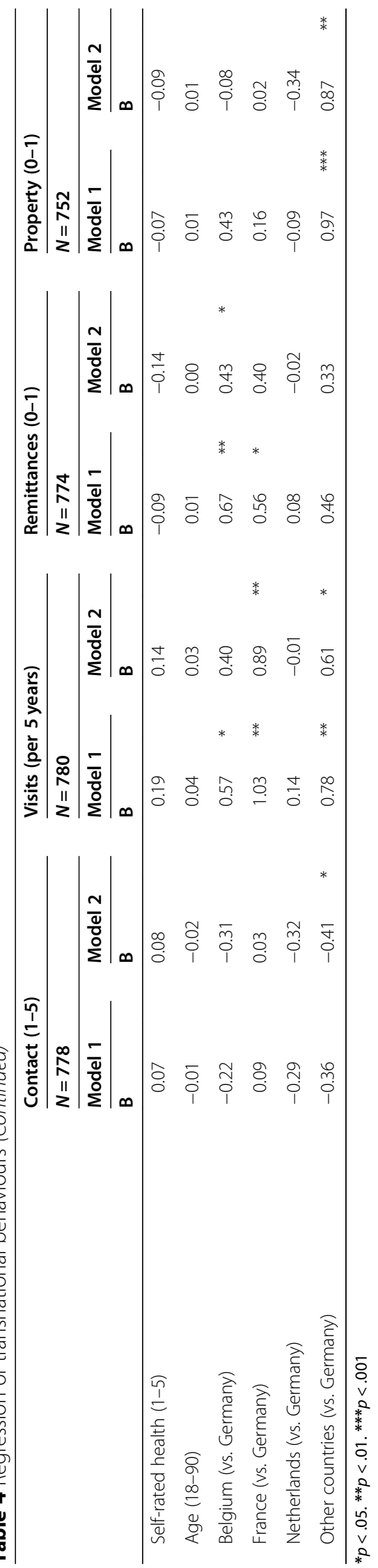


countries additionally reveal that Turkish men living in the Netherlands more often travel back to the origin country than those in France $(\mathrm{B}=.87 ; p=<.05)$. The independent variables add to the differences between the first generation and subsequent generations instead of explaining them. Further analyses with alternating reference categories (results not shown in Table 3) reveal that the difference between G1.5 and G3 can be explained by having a paid job and a feeling of connectivity with residence country nationals (Model 1: B for G1.5 vs. G3 $=.84$ $p=.002$; Model $2: \mathrm{B}=.56 p=.092$ ). F-change was significant in all twenty imputed datasets; $p<.05$.

While the transnational convoy is not relevant (Hypothesis $2 \mathrm{~b}$ ), both structural and socio-cultural indicators of integration are important for understanding remitting. Those owning property in the residence country are 21 percentage points more likely to remit than those who do not $(\mathrm{B}=.56)$ (Hypothesis $3 \mathrm{~b}$ ). (As with contact frequency, Table S3 in the Supplementary Material shows that controlled for only structural integration (Model 3), differences between some generations become more pronounced (G1.5 and G2 vs. G1). Also, having a paid job is a significant contributor to understanding remittance sending in that model). More religious attendance is associated with the likelihood of remitting $(\mathrm{B}=.26)$. Those attending everyday are thirty percentage points more likely to remit than those never attending (Hypothesis 4b). (Having a Turkish partner significantly adds to explaining remittances when controlled for socio-cultural integration only in Table S3. Furthermore, it abrogates the difference between G1 and G3. Combining the findings in the Supplementary Material regarding having a paid job and having a Turkish partner with Model 2 of Table 4, perhaps suggests that having a Turkish partner improves the financial situation, which, in turn, impacts remittance sending). Belgian residents are more likely to remit than German residents; a change in reference categories does not result in different findings. Regarding the difference in remitting between the generations; Model 2 shows a change in log-odds compared to Model 1. However, converted into percentages, no difference is noticeable. Additional analyses with alternating reference categories yield similar results. Model 1 and the extension to Model 2 increase our understanding of remittance behaviour in all twenty imputed datasets $(p<.001)$.

For transnational property ownership, only structural integration seems important. Compared to their counterparts not possessing assets in the residence country, those who do are thirty percentage points more likely to also own property in Turkey ( $\mathrm{B}=$ 1.70) (Hypothesis 3b). Living in 'other' countries increases the likelihood of owning property in Turkey, in comparison to living in Germany. Additional analysis with alternating reference countries shows that living in 'other' countries also differs from living in Belgium $(\mathrm{B}=.94 ; p<.010)$, France $(\mathrm{B}=.84 ; p<.05)$ and the Netherlands $(\mathrm{B}=1.20$; $p<.010$ ). Model 2 in Table 4 suggests that generational differences in owning property in Turkey increase compared to Model 1. However, as with remittance sending, when we transform log odds to percentages, generational differences in the likelihood of owning property in Turkey do not change. Subsequent analyses with the other generations as reference categories result in similar findings. Model 1 and the extension to Model 2 show an improved fit in all twenty imputed datasets $(p<.001)$.

Summarising the results of the regression analyses, few independent variables and no control variables contribute to a further understanding of differences between 
generations. No sustenance was found for Hypothesis $2 \mathrm{~b}$. We found partial support for Hypothesis $3 \mathrm{~b}$, i.e., for three transnational behaviours and for two structural integration characteristics. We also found some support for Hypothesis $4 \mathrm{~b}$; two of the four indicators of socio-cultural integration that we employed were relevant to understanding specific transnational behaviours.

\section{Discussion}

This paper investigates differences in transnational behaviour among generations of Turkish migrants in three domains: social (contact frequency and visiting), economic (remittances and property ownership in origin country) and political (voting). Specifically, we examined whether and how a transnational social convoy and indicators of structural and socio-cultural integration account for generational differences in transnational contact, visits, remittances and property.

We find that visiting, remitting, property ownership and voting diminish across generations (Hypothesis 1). For visiting and property ownership in Turkey, we see a linear descending pattern from G1 to G3. This may be because these behaviours are particularly important for those considering a permanent return to the origin country. Boccagni (2015) shows that assets such as houses, entrepreneurial activities or plots of land in the origin country are important if one aspires to return permanently. Maintenance on the property is done during these visits; having invested in property also imposes an obligation to go there (Van der Horst 2010). Visits can foster a connection to the country that one may someday return to, as physical presence in the longed-for place remains the gold standard in transnational contact (Mason 2004). The wish for return migration is likely to descend across generations. In fact, G2 and G3 cannot even return; they never actually migrated.

Remitting and voting descend across generations in a more differentiated manner. Scholars have disputed the linear erosion of transnational behaviours for later generations (Jones-Correa 2002). Using a generational comparative perspective, our study confirms these predominantly only second-generation targeted studies. For contact frequency, no generational differences were observed, even despite a smaller transnational convoy across generations and despite visiting behaviour diminishing linearly. This is a remarkable finding underlining the importance of "the power of being raised in a transnational social field" (Levitt 2009, 1225). As such, children of migrants are imbued with norms, practices, people, objects and know-how from ancestral homelands, enabling them to negotiate transnational lifestyles. Our results add to this much-referenced notion by indicating that this mechanism extends to later generations as well. The currently low-cost character of transnational contact via ICT might facilitate this process. Scholars have argued that ICT opportunities have altered the potential for transnational connections (Waldinger 2008).

Hypotheses $2 \mathrm{a}$ and $2 \mathrm{~b}$ considered the transnational convoy; the first explanatory concept underpinning transnational behaviour. Hypothesis 2a expected earlier generations to have greater transnational convoys than later generations, which was partly supported. Although this finding may seem common knowledge, little comparative research among multiple generations and transnational network sizes has been done. Systematic analysis, such as that employed in the current study, is therefore a valuable addition to the field. Relatively many respondents of G1.5 and 
G2 have parents in Turkey. This possibly reflects the sampling frame: the 2000 Families study started sampling in Turkey, thereby excluding families and social networks who emigrated in their entirety and stayed in Europe. Hypothesis $2 \mathrm{~b}$, the greater the transnational convoy, the more transnational behaviour, was not supported. We captured the transnational convoy by parents and close people living in the origin country. According to the convoy model of social relations (Kahn and Antonucci 1980), they are, together with other immediate family members, closest to the focal person. There may be other close relationships in the origin country that are imperative for transnational behaviour that we did not detect. Another explanation could be found in 'place belongingness' (Antonsich 2010). In addition to people, memories of a certain place can provide belonging, which is why people may engage in transnational behaviours. For instance, childhood playgrounds or ancestors' former houses may be crucial to people's personal histories. These sources of transnational behaviours were beyond the scope of this study. Because the transnational convoy had no meaning in determining transnational behaviour, differences in transnational convoy size were not able to illuminate generational differences in cross-border activities.

Hypotheses $3 \mathrm{a}$ and $3 \mathrm{~b}$ investigated the effect of structural integration on transnational behaviour and formed the second explanation to understand generational differences in transnational behaviour. Hypothesis $3 \mathrm{a}$ expected that later generations are more structurally integrated than earlier generations and was partially supported. Pertaining to Hypothesis $3 \mathrm{~b}$, we find that indicators of structural integration increase (the likelihood of) some transnational behaviours. We find this for indicators of financial resources, not for educational level. This is unsurprising, as two indicators of economic transnational behaviour (remitting and property ownership) were impacted by financial resources and one of social transnational behaviour (visiting). The latter also requires financial means because of travel and staying costs. Zooming into the dynamics undergirding these findings lays bare some of the complexity involved in generational comparisons. In G1, few people have a job, whereas many people in other generations work; meanwhile, visits are highest in G1. G1's unemployed respondents are apparently similar to the other generations' employed respondents when it regards visiting Turkey. This seems to indicate that structural resources are more important for later generations in predicting visiting frequency than for G1. However, this conclusion may be farfetched: G1's structural integration is, possibly, to a lesser extent caught by indicators used than other generations'. We used information on educational level, employment status and owning property in the residence country. Income is at the heart of structural resources. Yet, information on peoples' income was left out of analyses because of missing data that were unaccounted for. Especially for G1, employment status as a proxy for income might not apply because most of them are retired. We are thus reluctant to conclude that structural integration is more important for later than for earlier generations in steering transnational behaviour. Comparing generations at non-similar ages inevitably results in some issues regarding the distribution of variables, as age effects are found among many aspects of life (Safi 2017). Only cohort-sequential analysis may resolve this problem, but data collection enabling such a design is long- 
lasting and costly, and hitherto unavailable. The 2000 Families Survey provides us with more possibilities to allow generational comparisons than other data.

A last theoretical clue highlighted the role of socio-cultural integration. We found support for Hypothesis 4a: socio-cultural integration into residence society was more developed for later than for earlier generations. Although scholars have advocated for the coexistence of integration into residence society and transnational connections (Erdal and Oeppen 2013), our results lend some support for more socio-cultural integration to weaken transnational participation (Hypothesis 4b). Prior studies yielded similar findings (Cela et al. 2013; Fokkema et al. 2012). The positive effects of religious attendance is contrary to the idea of ethnic social networks in the residence country superseding the need or longing for the country of origin. Quite the opposite, often going to the mosque intensifies contact frequency and probability of remittance sending. A complementary mechanism may be at work (Snel et al. 2006): relationships with people with similar migration backgrounds might install a yearning for a country (and its inhabitants) left behind-although perhaps by forefathers. Thus, embedding in the migrant community in the residence country reinforces transnational behaviour, rather than 'replacing' it. Yet, another explanation for the effect of religious attendance on remittance sending is viable: remitting to the origin country can be a means of Islamic alms giving (Erdal 2012). Though the effect of religious attendance on transnational contact may also be an expression of piety, for the association between connectivity with residence country nationals and visits, an alternative explanation is less obvious. We therefore conclude, based on our results, that we cannot simply disregard a negative influence of socio-cultural integration on transnational behaviour.

We found that generations differed in their levels of integration and that both indicators of structural and socio-cultural integration influenced transnational behaviours. This resulted in an improved understanding of why G1.5 and G3 differ in their visiting behaviour. If they were employed to the same extent and if they had equal feelings of connectivity to residence country nationals, their number of visits to Turkey would be alike. However, it seems puzzling that we were unable to explain further generational differences and to illuminate what generation means when we observe generational differences in transnational behaviour. Perhaps the differences between generations or effects of independent variables were not strong enough to stay afloat in a pooled sample. There may also be contrary mechanisms being at work in different generations (Safi 2017), ultimately defusing the outlined mechanisms. As discussed above, the distance between concepts (structural and socio-cultural integration) and indicators is relatively large. Though studies have investigated the interaction between integration and transnational engagements, the field is not theoretically mature (Erdal and Oeppen 2013). Improved operationalisation and theoretical persuasiveness are required to better explain the differential impact of integration on transnational behaviours across generations.

Conceptual ambiguity and a lack of clear, tested indicators also apply to the concept of transnational behaviour. It is illustrative that our indicators correlate only in a negligible way. Others have also questioned 'transnational behaviour' as a concept. For instance, (Waldinger (2008), 24) states: "As a rule, cross-border activities and exchanges do not cluster together". There may even be a compensatory or amplifying mechanism between two or more of these behaviours. We did not unravel these processes and 
suggest future research investigates how different transnational behaviours relate to each other.

We find that residence countries are important to control for. Transnational behaviours are, even with the effect of integration held constant, partly dependent on residence country. In this paper, we did not aim to test how transnational behaviours vary by residence country. As also no clear pattern in importance of residence countries is detected, no further discussion is devoted to these findings.

There are a few other issues demanding consideration. We only studied men, not women. The gendered impact of transnational convoys on transnational behaviours has, to the best of our knowledge, not been extensively studied. Some previous studies suggest that the effect of perceived social distance to the settlement society on transnational behaviour is greater for men than for women, in first generation migrants (Itzigsohn and Giorguli-Saucedo 2005). In that same study, the impact of structural integration on transnational practices was greater for women than for men. In a study on the second generation, the effect of structural integration on return intentions were positive for men while negative for women, but no significant differences were found for transnational behaviours (Bachmeier et al. 2013). These studies suggest that there are gendered dynamics in transnational behaviours, and that these are dependent on generation. Our results are therefore only generalizable for Turkish men living in Europe, and, due to the sampling method, only for those with family living in Turkey. As Turkish migrants are known to be highly transnational (Ehrkamp 2005), we also emphasize the particularity of the findings here and are reserved in generalizing to other populations.

The way we drew our generations from the data also requires some attention. From a migratory point of view, our G3 sample consists of second-generation migrants and third generation migrants, which are conceivably incomparable (Rumbaut 2004). However, we know that for all G3 respondents their grandfather was the first migrant to Europe in their family and not their parent(s). This makes the 'second generation' label also not fully applicable to them. In addition, the 2000 Families study is a family study; therefore, we followed the data structure and did not distinguish between the two types of the demographic third generation.

External voting is a prominent indicator of transnational political engagement (Boccagni et al. 2016) and provides us with an understanding of generational differences in transnational political behaviour. Though important, it is a rather lean operationalisation of transnational political engagement. Using secondary data, we were unable to incorporate other modes of political organisation, such as membership in a political party in the origin country, active involvement in political campaigns or membership in hometown civic associations (Guarnizo et al. 2003).

In conclusion, our contribution to the field of transnational behaviours is fivefold. First, we provided insight into which and how transnational behaviours wane across generations and which do not, for the population under study. It is a notable finding that transnational contact with friends or relatives has not changed across generations. For visiting and property ownership we see a more or less linear shaped decline across generations, while this is different for voting and remitting. This underscores the suggestion that different generations employ different constellations of transnational behaviours (Safi 2017). Second, to gain a more established understanding of the drivers of transnational behaviours, we added to research showing that structural integration is 
associated with more transnational behaviour (Carling and Hoelscher 2013; Fokkema et al. 2012; Tamaki 2011). We showed that this is the case across generations, not only among first- or second-generation migrants. Third, our findings contrast with an emerging line of reasoning in which scholars suggest that socio-cultural integration is independent of transnational behaviours (Carling and Hoelscher 2013; Snel et al. 2006). Two of the four indicators we employed for socio-cultural integration impact - to different degrees - transnational behaviours. Moreover, connectivity with residence country nationals can be held partially accountable for annulling the difference between G1.5 and G3 in our sample. Future research should theorise more on exactly which forms of socio-cultural integration are independent of transnational behaviours and for whom. Fourth, our findings suggest a larger role for integration to associate transnational behaviours than the transnational convoy. Apparently, one's relationship with the residence country is more important for transnational behaviour than relationships with close others in the origin country. To the best of our knowledge, previous research has not specifically focused on the relationships between the social convoy and integration on the one hand and transnational behaviours on the other. We lack sufficient insights to interpret this finding further. We suggest, however, that it merits future scholarly attention. Fifth, in a more generic sense, by investigating one of Europe's largest migrant populations' successive generations, this study aids in describing the change in patterns of integration and transnational behaviours in Europe (Ryder 1965). We detected changes in transnational social convoys, in integration and in transnational behaviour. Nonetheless, our conclusion is that migrant offspring lives, until the third generation, continue to be shaped by factors both "here" and "there".

\section{Supplementary information}

Supplementary information accompanies this paper at https://doi.org/10.1186/s40878-020-00206-0.

Additional file 1. Supplementary Material.

Acknowledgements

Not applicable.

Authors' contributions

The research idea was conceived by TF. JK performed the statistical analyses with the aid of TVT. JK drafted the manuscript. All authors critically revised several versions of the manuscript for intellectual content. The authors read and approved the final manuscript.

Funding

The "2000 Families: Migration Histories of Turks in Europe" project is funded by the New Opportunities for Research Funding Agency Co-operation in Europe under their Migration Programme (NORFACE grant 235548). Suanet's work was supported by a Veni grant from the Netherlands Research Council (NWO file number 451-14-019). Fokkema's research is part of the "Families in Context" project, funded by an Advanced Investigator Grant of the European Research Council (ERC grant 324211).

\section{Availability of data and materials}

The data as well as a codebook can be freely accessed at www.2000families.org.

Competing interests

There are no conflicts of interest.

\section{Author details}

${ }^{1}$ Department of Erasmus School of Social and Behavioural Sciences, Erasmus University Rotterdam, Burgemeester Oudlaan 50, 3062, PA, Rotterdam, The Netherlands. ²Department of Sociology, Vrije Universiteit Amsterdam, De Boelelaan, 1081, HV, Amsterdam, The Netherlands. ${ }^{3}$ Netherlands Interdisciplinary Demographic Institute (NIDI-KNAW), University of Groningen, Lange Houtstraat 19, 2511, CV, The Hague, The Netherlands. 
Received: 8 January 2020 Accepted: 24 September 2020

Published online: 26 November 2020

\section{References}

Alba, R., Logan, J., Lutz, A., \& Stults, B. (2002). Only English by the third generation? Loss and preservation of the mother tongue among the grandchildren of contemporary immigrants. Demography, 39(3), 467-484. https://doi.org/10.1353/ dem.2002.0023.

Algan, Y., Dustmann, C., Glitz, A., \& Manning, A. (2009). The economic situation of first and second-generation immigrants in France, Germany and the United Kingdom. Economic Journal, 120(542), 4-30. https://doi.org/10.1111/j.1468-0297.2009. 02338.x.

Antonsich, M. (2010). Searching for belonging - An analytical framework. Geography Compass, 4(6), 644-659. https://doi.org/ 10.1111/j.1749-8198.2009.00317.X.

Bachmeier, J., Lessard, L., \& Fokkema, T. (2013). The gendered dynamics of integration and transnational engagement among second-generation adults in Europe. In L. Oso, \& N. Ribas Mateos (Eds.), The international handbook on gender, migration and transnationalism. Global and development perspectives (pp. 268-293). Cheltenham: Edward Elgar Publishing. https:// doi.org/10.4337/9781781951477.00022.

Boccagni, P. (2012). Even a transnational social field must have its boundaries: Methodological options, potentials and dilemmas for researching transnationalism. In C. Vargas-Silva (Ed.), Handbook of research methods in migration (pp. 295318). Cheltenham: Edward Elgar Publishing.

Boccagni, P. (2015). Burden, blessing or both? On the mixed role of transnational ties in migrant informal social support. International Sociology, 30(3), 250-268. https://doi.org/10.1177/0268580915570508.

Boccagni, P., Lafleur, J., \& Levitt, P. (2016). Transnational politics as cultural circulation: Toward a conceptual understanding of migrant political participation on the move. Mobilities, 11(3), 444-463. https://doi.org/10.1080/17450101.2014.1000023.

Bolzman, C. (2013). Ageing immigrants and the question of return: New answers to an old dilemma? In J. Percival (Ed.), Return migration in later life (pp. 67-87). Chicago: Policy Press. https://doi.org/10.1332/policypress/9781447301226.003. 0004.

Carling, J. (2008). The determinants of migrant remittances. Oxford Review of Economic Policy, 24(3), 582-599. https://doi.org/ 10.1093/oxrep/grn022.

Carling, J., \& Hoelscher, K. (2013). The capacity and desire to remit: Comparing local and transnational influences. Journal of Ethnic and Migration Studies, 39(6), 939-958. https://doi.org/10.1080/1369183X.2013.765657.

Cela, E., Fokkema, T., \& Ambrosetti, E. (2013). Variation in transnationalism among eastern European migrants in Italy: The role of duration of residence and integration. Southeast European and Black Sea Studies, 13(2), 195-209. https://doi.org/10. 1080/14683857.2013.789671.

Crul, M., \& Vermeulen, H. (2003). The second generation in Europe. International Migration Review, 37(4), 965-986. https://doi. org/10.1111/j.1747-7379.2003.tb00166.x.

Dagevos, J. (2001). Perspectief op integratie: Over de sociaal-culturele en structurele integratie van etnische minderheden in Nederland [Integration perspectives: About the socio-cultural and structural integration of ethnic minorities in The Netherlands]. Den Haag: Wetenschappelijke Raad voor het Regeringsbeleid.

Dalakoglou, D. (2010). Migrating-remitting-'building'-dwelling: House-making as 'proxy' presence in Postsocialist Albania. Journal of the Royal Anthropological Institute, 16(4), 761-777. https://doi.org/10.1111/j.1467-9655.2010.01652.x.

Ehrkamp, P. (2005). Placing identities: Transnational practices and local attachments of Turkish immigrants in Germany. Journal of Ethnic and Migration Studies, 31(2), 345-364. https://doi.org/10.1080/1369183042000339963.

Erdal, M. (2012). Who is the money for? Remittances within and beyond the household in Pakistan. Asian and Pacific Migration Journal, 21(4), 437-457. https://doi.org/10.1177/011719681202100401.

Erdal, M., \& Oeppen, C. (2013). Migrant balancing acts: Understanding the interactions between integration and transnationalism. Journal of Ethnic and Migration Studies, 39(6), 867-884. https://doi.org/10.1080/1369183X.2013.765647.

Ersanilli, E., \& Koopmans, R. (2010). Rewarding integration? Citizenship regulations and the socio-cultural integration of immigrants in the Netherlands, France and Germany. Journal of Ethnic and Migration Studies, 36(5), 773-791. https://doi. org/10.1080/13691831003764318.

Espiritu, Y. (2003). Home bound: Filipino American lives across cultures, communities, and countries. Berkeley and Los Angeles: University of California Press.

Fokkema, T., Cela, E., \& Ambrosetti, E. (2013). Giving from the heart or from the ego? Motives behind remittances of the second generation in Europe. International Migration Review, 47(3), 539-572. https://doi.org/10.1111/imre.12032.

Fokkema, T., \& de Haas, H. (2015). Pre- and post-migration determinants of socio-cultural integration of African immigrants in Italy and Spain. International Migration, 53(6), 3-26. https://doi.org/10.1111/j.1468-2435.2011.00687.x.

Fokkema, T., Lessard-Phillips, L., Bachmeier, J., \& Brown, S. (2012). The link between the transnational behaviour and integration of the second generation in European and American cities. Nordic Journal of Migration Research, 2(2), $111-$ 123. https://doi.org/10.2478/v10202-011-0033-X.

Ganzeboom, H., Sozeri, E., Guveli, A., \& Bayrakdar, S. (2015). 2000 families: Migration histories of Turks in Europe. Amsterdam Data Documentation, Vrije Universiteit.

Glick Schiller, N., Basch, L., \& Blanc-Szanton, C. (1992). Transnationalism: A new analytic framework for understanding migration. Annals of the New York Academy of Sciences, 645(1), 1-24. https://doi.org/10.1111/j.1749-6632.1992.tb33484.x.

Guarnizo, L., Portes, A., \& Haller, W. (2003). Assimilation and transnationalism: Determinants of transnational political action among contemporary migrants. American Journal of Sociology, 108(6), 1211-1248. https://doi.org/10.1086/375195.

Guveli, A., Ganzeboom, H., Baykara-Krumme, H., Bayrakdar, S., Eroglu, S., Hamutci, B., ... Sözeri, E. (2016). 2000 families: Migration histories of Turks in Europe. ZA5957 Data file Version 2.0.0. Cologne: GESIS Data Archive. https://doi.org/10.4232/ 1.12673.

Itzigsohn, J., \& Giorguli-Saucedo, S. (2002). Immigrant incorporation and sociocultural transnationalism. International Migration Review. 36(3):766-798. https://doi.org/10.1111/j.1747-7379.2002.tb00104.x. 
Itzigsohn, J., \& Giorguli-Saucedo, S. (2005). Incorporation, transnationalism, and gender: Immigrant incorporation and transnational partitipation as gendered processes. International Migration Review, 39(4), 895-920. https://doi.org/10.1111/j. 1747-7379.2005.tb00293.x

Jones-Correa, M. (2002). The study of transnationalism among the children of immigrants: Where we are and where we should be headed. In P. Levitt, \& M. Waters (Eds.), The changing face of home: The transnational lives of the second generation (pp. 221-241). New York: Russell Sage Foundation.

Kahn, R., \& Antonucci, T. (1980). Convoys over the life course: Attachment, roles, and social support. In P. Baltes, \& O. Brim (Eds.), Life-span development and behavior (pp. 253-286). New York: Academic.

King, R., \& Christou, A. (2010). Cultural geographies of counter-diasporic migration: Perspectives from the study of secondgeneration 'returnees' to Greece. Population, Space and Place, 16(2), 103-119. https://doi.org/10.1002/psp.543.

Leichtman, M. A. (2005). The legacy of transnational lives: Beyond the first generation of Lebanese in Senegal. Ethnic and Racial Studies, 28(4), 663-686. https://doi.org/10.1080/13569320500092794.

Levitt, P. (2003). Keeping feet in both worlds: Transnational practices and immigrant incorporation in the United States. In C. Joppke, \& E. Morawska (Eds.), Toward assimilation and citizenship: Immigrants in Liberal nation-states (pp. 177-194). New York: Palgrave. https://doi.org/10.1057/9780230554795_7.

Levitt, P. (2009). Roots and routes: Understanding the lives of the second generation transnationally. Journal of Ethnic and Migration Studies, 35(7), 1225-1242. https://doi.org/10.1080/13691830903006309.

Levitt, P., \& Glick Schiller, N. (2004). Conceptualizing simultaneity: A transnational social field perspective on society. International Migration Review, 38(3), 1002-1039. https://doi.org/10.1111/j.1747-7379.2004.tb00227.x.

Levitt, P., \& Jaworsky, B. (2007). Transnational migration studies: Past developments and future trends. Annual Review of Sociology, 33(1), 129-156. https://doi.org/10.1146/annurev.soc.33.040406.131816.

Mason, J. (2004). Managing kinship over long distances: The significance of 'the visit. Social Policy and Society, 3(4), 421-429. https://doi.org/10.1017/S1474746404002052.

Mügge, L. (2011). Beyond Dutch borders: Transnational politics among colonial migrants, guest workers and the second generation. Amsterdam: Amsterdam University Press. https://doi.org/10.5117/9789089642448.

Østergaard-Nielsen, E. (2001). Transnational political practices and the receiving state: Turks and Kurds in Germany and the Netherlands. Global Networks, 1(3), 261-282. https://doi.org/10.1111/1471-0374.00016.

Rumbaut, R. (2004). Ages, life stages, and generational cohorts: Decomposing the immigrant first and second generations in the United States. International Migration Review, 38(3), 1160-1205. https://doi.org/10.1111/j.1747-7379.2004.tb00232.x.

Ryder, N. (1965). The cohort as a concept in the study of social change. American Sociological Review, 30(6), 843-861. https:// doi.org/10.2307/2090964.

Safi, M. (2017). Varieties of transnationalism and its changing determinants across immigrant generations: Evidence from French data. International Migration Review, 1-45. https://doi.org/10.1111/imre.12314.

Schans, D. (2009). Transnational family ties of immigrants in the Netherlands. Ethnic and Racial Studies, 32(7), 1164-1182 https://doi.org/10.1080/01419870902763852

Scholten, P. (2011). Framing immigrant integration: Dutch research-policy dialogues in comparative perspective. Amsterdam: Amsterdam University Press. https://doi.org/10.1017/CBO9781107415324.004

Schunck, R. (2014). Transnational activities and immigrant integration in Germany. Cham: Springer. https://doi.org/10.1007/9783-319-03928-2_6.

Snel, E., Engbersen, G., \& Leerkes, A. (2006). Transnational involvement and social integration. Global Networks, 6(3), 285-308. https://doi.org/10.1111/j.1471-0374.2006.00145.x.

Tamaki, E. (2011). Transnational home engagement among Latino and Asian Americans: Resources and motivation. International Migration Review, 45(1), 148-173. https://doi.org/10.1111/j.1747-7379.2010.00842.x.

Trieu, M. M., Vargas, N., \& Gonzales, R. G. (2016). Transnational patterns among Asian American and Latina/o American children of immigrants from Southern California. Journal of Ethnic and Migration Studies, 42(7), 1177-1198. https://doi.org/ 10.1080/1369183x.2015.1113865.

Van der Horst, H. (2010). Dwellings in transnational lives: A biographical perspective on 'Turkish-Dutch' houses in Turkey. Journal of Ethnic and Migration Studies, 36(7), 1175-1192. https://doi.org/10.1080/1369183X.2010.481616.

Vertovec, S. (2009). Transnationalism. New York: Routledge. https://doi.org/10.4324/9780203927083.

Von Hippel, P. (2007). Regression with missing Y's: An improved strategy for analyzing multiply imputed data. Sociological Methodology, 37(1), 83-117. https://doi.org/10.1111/j.1467-9531.2007.00180.x.

Waldinger, R. (2008). Between "here" and "there": Immigrant cross-border activities and loyalties. International Migration Review, 42(1), 3-29. https://doi.org/10.1111/j.1747-7379.2007.00112.x.

Wessendorf, S. (2013). Second-generation transnationalism and roots migration: Cross-border lives. London: Routledge. https:// doi.org/10.4324/9781315607962.

\section{Publisher's Note}

Springer Nature remains neutral with regard to jurisdictional claims in published maps and institutional affiliations. 